\title{
POS- EN TELEKOMMUNIKASIE IN SUID-AFRIKA EN ELDERS IN AFRIKA
}

Dit is vir ons 'n voorreg om 'n bydrae - beskeie soos dit mag wees - te kan lewer tot 'n oorsig van ons land se posen telekommunikasiedienste. Aan prof. Coetzee is ons dank verskuldig vir 'n baie interessante en insiggewende inleidende oorsig. Ons het met groot belangstelling daarop gelet en is veral getref deur sy stelling dat kommunikasiemediums soos die lugvaart en die radio deur sommige van die nuwe Afrikastate aangegryp word as "bewyse" van hulle pas verkreë onafhanklikheid en selfbeskikkingsreg. Met ander woorde, as statussimbole op nasionale vlak.

Ons in die Poskantoor van Suid-Afrika is uiteraard ook trots op die verskeie kommunikasiedienste wat ons lewer. By wetgewing is hulle aan ons opgedra en waar dit ons voorreg is om die betrokke dienste aan die samelewing te lewer, is dit tegelyk ook ons plig. 'n Plig wat ons met groot graagte nakom want in die proses lewer ons aan die gemeenskap 'n diens wat inderdaad 'n onmisbare skakel in die roetine van die daaglikse lewe geword het. Juis daarom beskou ons nie die kommunikasienetwerk van die Suid-Afrikaanse Poskantoor as 'n statussimbool nie, dog as 'n noodsaaklikheid.

En omdat dit 'n noodsaaklikheid is, is en word die posen telekommunikasiedienste hier te lande voortdurend uitgebrei, aangepas en gemoderniseer ten einde in veranderde en steeds toenemende behoeftes te voorsien. Hierin is en word meermale groot probleme ondervind, onder meer vanweë die lang afstande waaroor kommunikasiekanale verskaf en in stand gehou moet word. Maar ondanks hierdie hindernisse en ander soos ontoereikende personeel- en kapitaalvoorsiening, is oor die jare heen skouspelagtige vordering gemaak en word vir die toekoms verdere groot ontwikkelings beoog.

Ons is gevra om ook die kommunikasiedienste van ander Afrika-lande te behandel. Graag sou ons dit wou doen, maar ongelukkig kom ons voor die probleem te staan dat op hierdie gebied die inligting wat vrygestel word, te karig is om enigsins met gesag daaroor te kan praat of om 'n goeie vergelyking te kan tref. Wel weet ons dat die kommunikasiestelsels in 
die meeste van die betrokke lande nouliks vergelykbaar is met dié van Suid-Afrika. Elders brei ons ietwat hierop uit aan die hand van die gegewens wat wel beskikbaar is en wat uit die publikasies van die Internasionale Telekommunikasieunie verkry is.

Teen die agtergrond hiervan let ons nou meer bepaald op die vordering in die verskaffing en uitbouing van die Republiek se pos- en telekommunikasiedienste. Vir dié doel word die onderwerp graag onder twee hoofde behandel, te wete (i) die poskant en (ii) die telekommunikasiekant.

\section{Die poskant:}

Wat waarskynlik as die eerste poging tot poswerk in SuidAfrika beskou kan word, is die brief wat ongeveer dertien jaar na die ontdekking van die Kaap deur Pedro d'Ataide geskryf en in die nou geskiedkundige Poskantoorboom op Mosselbaai geplaas is. Vir die volgende honderd jaar was daar geen verwikkelings wat aan die posdiens gekoppel kan word nie, maar gedurende 1607 het seevaarders na en van die Ooste briewe onder groot klippe langs die kus van Tafelbaai geplaas in die hoop dat die briewe daar gevind en na hulle bestemmings vervoer sou word. Ook die eerste eeu na die vestiging van blankes aan die Kaap sien nog geen georganiseerde posdiens nie en eers in 1806, na die Britse besetting, word die eerste georganiseerde posdiens hier te lande deur die Staat op die been gebring. Dit was in Kaapstad gesetel en ons kan ons die feitlik naakte Hottentot wat indertyd gehuur is om die briewe te vervoer, met 'n paar briewe in 'n gesplete stok in die hand op sy drafstap deur die wilde wêreld van indertyd voorstel. Die Hottentotlopers was by verskillende punte langs die roete gestasioneer en die boere wat hulle gehuisves en versorg het, het vyf riksdalers (sowat R2) per maand daarvoor ontvang. 'n Primitiewe diens, maar tog een wat baie op prys gestel is en in 'n behoefte voorsien het.

In 1807 neem perderuiters oor en ons lees dat die diens toe "vinnig en gereeld" was. In dié stadium moes posgeld nog in kontant vooruitbetaal word, maar op 1 September 1853 word die eerste posseëls in gebruik geneem. Die posseëls was slegs geldig vir binnelandse gebruik; posgeld op posstukke na die buiteland moes steeds in kontant betaal word. Tot hiertoe het die posdiens ook slegs vir die vervoer van briewe voorsiening 
gemaak, maar in 1854 word die sogenaamde boekposdiens ingestel. Geleidelik vind verdere uitbreiding plaas en in 1870 bereik die posciens Kimberley na die ontdekking van diamante daar. Die eer ste posversending vanaf Kaapstad na Kimberley het bestaan uit 16 briewe en 26 boeke en koerante. Dit is ook omstreeks hierdie tyd dat kamele gebruik is vir die vervoer van pos in die Gordoniagebied.

'n Paar jaar later het die Posmeester van Bloemfontein nog met 'n vlag die aankoms van pos aangekondig en 'n tweede vlag - die slag 'n rooie - gehys om die gemeenskap te laat weet dat die pos gereed is om deur die poskantoorvenster afgehaal te word. In September 1886 is Johannesburg se eerste posmeester aangestel. Sy kantoor was gehuisves in 'n sinkpondok en besigheid is deur ' $n$ klein venstertjie verrig. Briewe is afgelewer deur op ' $n$ gegewe tyd die name daarop in alfabetiese volgorde uit te lees, maar hierdie probleem is opgelos deur die ingebruikneming van die eerste private posbusse in Johannesburg omstreeks 1887 en die instelling van die eerste straatafleweringsdiens tien jaar later.

In 1891 gaan die ou Zuid-Afrikaanse Republiek 'n posooreenkoms met Mosambiek aan en word 'n gereelde posdiens tussen Barberton en Lourenco Marques moontlik gemaak. Soortgelyke ooreenkomste word die jaar daarna met die Kaapkolonie en die Oranje-Vrystaat aangegaan.

In Natal is die eerste posdiens deur die militêre owerhede beheer; daar was een posversending per week tussen Pietermaritzburg en Durban. Die Hawemeester in Durban is gelas om briewe van skeepskapteins aan te neem en dié aan doeanebeamptes te oorhandig vir versending met die gereelde pos. Die "Rosebud" was indertyd 'n skoener wat gereeld tussen Durban en die Kaap gevaar het. Daar was ook 'n landroete oor Grahamstad, maar vanweë grensmoeilikhede was dit dikwels ontwrig en dit blyk dat pos ook oor land na Colesberg versend is.

Vanaf Durban is posversendings na die verskillende sendingstasies georganiseer en in 1852 is bekend gemaak dat sodanige versendings deel uitmaak van Natal se gereelde posdiens. Ander vervoermiddels soos die „Express"-diens van die "Natal Witness" kon egter ook gebruik word en dit is interessant om daarop te let dat die vervoertarief van die „Natal Witness" tot in 1843 op $5 \mathrm{c}$ per vel te staan gekom het. 
Ons gaan dus die nuwe eeu met 'n baie elementêre posdiens in, maar na Uniewording versnel die ontwikkelingstempo aansienlik, danksy beter pad- en spoorverbindings. In 1910 is daar 2,457 pos- en telegraafkantore en word die koördinasie van die dienste van die verskillende provinsies en die uitbreiding na al die provinsies van posdienste dadelik aangepak. In der waarheid is dit die begin van die opbouingsproses van die moderne en uitgebreide posdiens wat vandag hier te lande beskikbaar is.

Vroeg reeds het die Volksraad die noodsaaklikheid ingesien van ' $\mathrm{n}$ nuwe Wet om aan die veranderde toestande te voldoen. In 1911 is die Post Administratie en Scheepvaart-Kombinaties Verhinderingswet (No. 10 van 1911) dus aangeneem. Hierdie Wet het die plek ingeneem van die poswette wat voorheen in die Kaap, Natal, Oranje-Vrystaat en Transvaal van krag was, en eers in 1958 is dit in Afrikaans vertaal en is die bestaande Poswet in die plek daarvan op die statuutboek geplaas.

Voortspruitend uit die Poswet van 1911, is die landboupakketpos wat voor Unie slegs in Transvaal en Natal beskikbaar was, na die res van die Unie uitgebrei. Reg uit die staanspoor was dit baie gewild en van groot waarde vir 'n aansienlike deel van die bevolking. Vir ' $n$ tyd was dit ook in werking na Suidwes-Afrika en Swaziland, maar as gevolg van vervoermoeilikhede is die diens na daardie gebiede gestaak.

Die voordeel van die sirkulasie deur die land van koerante teen 'n goedkoop, trouens 'n onekonomiese, postarief is ingesien, en in 1911 is reëlings getref vir uitgewers van bona fide koerante wat by die Poskantoor geregistreer is om hulle koerante - ongeag die gewig daarvan - teen die lae tarief van 4 d. per eksemplaar deur die pos te stuur. Op 1 Junie 1925 is die posgeld verander tot $4 \mathrm{~d}$. per eksemplaar tot 8 onse gewig en $\frac{1}{2} d$. per eksemplaar van 8 ons tot 1 pond in gewig, en daarna teen die skaal van toepassing op drukwerk. Hierdie tarief geld vandag nog, behalwe dat die „pennie” deur "sent" vervang is.

Met die opening van die diamantvelde op Mooifontein in 1910 , is ' $n$ diens per motorkar ingestel vir die vervoer van pos tussen Bloemhof en Mooifontein. Drie ander motordienste is kort daarna in werking gestel en in werklikheid kan dit beskou word as die begin van die vervoer van pos per motorvoertuig in ons land. Namate die betroubaarheid van sodanige voertuie 
in die praktyk bewys is, is groter gebruik daarvan gemaak en in 1919 het die getal motordienste reeds gestyg tot 73 . Algaande het motordienste wyd en syd in gebruik gekom en toe die Suid-Afrikaanse Spoorweë hul padmotordiens ingevoer het as voedingslyne vir die spoorweg, het die Poskantoor ingestem om daardie dienste te gebruik, waar hulle aan vereistes voldoen.

Die „kontant-by-aflewering”-pakketposdiens, wat voorsiening gemaak het vir vervoer en aflewering van pakkette binne die Unie, Basoetoland, Betsjoeanaland-Protektoraat en Swaziland is in Junie 1925 ingestel.

In 1931 is 'n nuwe regulasie ingevoer met die oog op die vinniger afhandeling en aflewering van briewe by straatadresse. Huisbewoners moes naamlik sorg vir 'n afleweringsplek vir pos, d.w.s. 'n bussie by die hek in gevalle waar die woning meer as 60 voet van die straat af geleë is, en in gevalle waar die woning minder as 60 voet van die straat af geleë is, 'n opening vir briewe in die voordeur.

Die „besigheidsantwoorddiens” is op 1 April 1934 ingevoer.

Die ontwikkeling van die land se handel met oorsese lande word in 'n groot mate weerspieël in die gebruik van die pakketposdiens. Ten einde vir die ordelike en doeltreffende wisseling van pakkette voorsiening te mak, is ooreenkomste dus vir direkte wederkerige pakketposdienste met 'n groot getal ander lande aangegaan.

Die uitbreek van die Tweede Wêreldoorlog lui 'n tydperk in toe daar van posuitbreiding min sprake was. Na die beëindiging van vyandelikhede - eweas op feitlik elke ander terrein in ons land - neem die ontwikkelingstempo weer toe. Dié keer so snel dat die Departement nie oral en altyd kon voorbly met die voorsiening van geskikte en toereikende akkommodasie vir die doeltreffende verrigting van poswerksaamhede nie. Desondanks lewer Suid-Afrika steeds 'n posdiens wat in omvang, modernheid en doeltreffendheid beter as goed vergelyk met die beste in die wêreld, terwyl hy daarop roem dat sy tariewe van die laagste ter wêreld is.

Reeds is daar 3,148 poskantore - geleë tot in die verste uithoeke van ons uitgestrekte land - maar nuwes word voortdurend gestig. In plaas van die eertydse posdraer, perderuiter en poskoets, maak ons vandag gebruik van 'n geïntegreerde netwerk van moderne pad-, spoor-, lug- en seeverbindings. Ons 


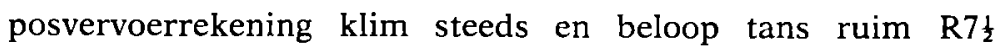
miljoen elke jaar. Die volgende enkele gegewens spreek vir hulleself:

$\begin{array}{lrr} & 1935 & 1965 \\ \text { Posstukke gehanteer } & \mathrm{R} 345,327,000 & \mathrm{R} 1,109,667,000 \\ \text { Private posbusse } & 33,550 & 179,480 \\ \text { Gelisensieerde posfrankeermasjiene } & 414 & 5,637 \\ \text { Besigheidsantwoorddienslisensies } & 64 & 2,486 \\ \text { Posinkomste } & 4,548,000 & 33,046,000\end{array}$

Oor die lugposdiens verskyn die volgende interessante paragraaf in die Posmeester-generaal se jaarverslag van die boekjaar 1935/36:

„Die ontwikkeling van die lugpos is miskien vandag die uitstaande kenmerk van die internasionale posdiens en daar bestaan min twyfel dat die versending oor lang afstande van alle briefposte per lug eerlank 'n wêreldwye gebruik sal wees."

Hierdie voorspelling is gemaak pas drie jaar nadat die eerste lugposdiens na en van die buiteland - naamlik tussen Londen en Kaapstad - deur Imperial Airways Limited ingestel is. Vandag word lugposte gewissel met lande tot in die verste uithoeke van die aardbol en die mate waarin daardie vroeë voorspelling bewaarheid is, blyk daaruit dat gedurende die boekjaar 1964/65 nie minder nie as 974,000 pond lugpos na die buiteland versend is, teenoor 48,000 pond in $1934 / 35$ en 587,000 pond in $1954 / 55$.

Maar die ontwikkeling van die binnelandse lugposdiens was selfs vinniger en skouspelagtiger. Die eerste binnelandse lugposdiens in Suid-Afrika is in 1925 ingestel en wel tussen Kaapstad en Durban. Hierna volg in 1929 'n soortgelyke diens tussen Kaapstad, Port Elizabeth, Oos-Londen en Durban met verbindings na Bloemfontein en Johannesburg en 'n verdere ontwikkeling in 1933 toe 'n regstreekse diens tussen Durban en die Randse Lughawe op Germiston ingestel is. Al hierdie dienste is deur private ondernemings gelewer, maar gedurende 1934 tree die Regering self tot die binnelandse lugdienste toe en die Unie-lugdienste van die spoorweg-administrasie vervoer reeds in 1938 en 1939 onderskeidelik 986,000 en 1,198,000 pond lugpos oor die binnelandse roetes. In dié stadium is die diens 
vanweë die Tweede Wêreldoorlog vir sowat ses jaar onderbreek, maar na die hervatting daarvan in Mei 1946, styg die gebruik wat daarvan gemaak word so vinnig dat gedurende die boekjaar 1949/50 meer as 2 miljoen pond pos vervoer word. Vir die boekjaar 1964/65 beloop die gewig byna $3 \frac{1}{2}$ miljoen pond.

Vir die vervoer van ons pos na die buiteland, word uiteraard ook gebruik gemaak van die seeposdiens. Die eerste posbootdiens het in 1815 begin toe snelvarende skepe deur die Britse Regering gebruik is om maandeliks van die Teems te vertrek met pos en passasiers vir die Kaap, Mauritius en Indië. Die heel eerste posboot het die Kaap in 114 dae bereik, nadat dit Madeira en Rio de Janeiro aangedoen het. Op 18 Oktober 1825 kom die eerste stoomskip - die "Enterprise" van 500 ton - Tafelbaai vanaf Engeland binnegevaar. Haar aankoms - 58 dae na haar vertrek uit Falmouth - is met groot opgewondenheid begroet en skole en besighede is gesluit om haar te kon verwelkom.

Hierna het nog sowat dertig jaar verloop voordat 'n werklik gereelde posbootdiens deur die „Union Line” tussen Engeland en Suid-Afrika ingestel is. In 1857 is die eerste vaste poskontrak tussen die Kaapse Regering en die „Union Line” aangegaan en in daardie dae is ooreengekom dat die Maatskappy se bote die reis tussen Southampton en Kaapstad in nie meer nie as $\mathbf{4 2}$ dae sou aflê. Sedertdien is die Union Castle Steamship Company nog altyd die vernaamste karweier van ons buitelandse seeposte en tans bestaan met hulle 'n vaste kontrak waarvolgens hulle elke jaar R800,000 vir hulle dienste ontvang. Die duur van die reis tussen Southampton en Kaapstad is intussen verminder na twaalf dae en wanneer die posboot nou elke week uit Southampton in Tafelbaai aankom, word gemiddeld agtien spoorwegwaens gevul met possakke vir binnelandse bestemmings, benewens die pos vir behandeling in Kaapstad self. Ander rederye vervoer ook 'n aansienlike hoeveelheid pos na die V.S.A., die Oos- en Weskus, Australië en die Verre-Ooste.

In Johannesburg - ons grootste possorteer- en transitokantoor, waar daagliks 'n enorme getal possakke ontvang en versend word, is reeds gedurende 1935 'n ondergrondse postonnel en vervoerbandstelsel in gebruik geneem om possakke tussen die stasie en die poskantoorgebou te vervoer. In 1956 
is dit verander en na die nuwe stasie verleng (tans is dit sowat 'n myl lank) en ons meen dat dit die grootste in die wêreld is. Ruim 35,000 possakke word elke week op dié wyse vervoer en die gemiddelde tydsduur vandat 'n possak by die poskantoor weggestuur is totdat dit die verste perron bereik, is slegs vyftien minute. Die gebruik van die tonnelstelsel met sy aanverwante onderaardse poskamer, hysbande en vervoerbande, bespaar ons jaarliks ' $n$ geweldige hoeveelheid tyd, arbeid en motorvervoer. In Kaapstad is 'n soortgelyke postonnel reeds gedeeltelik tussen die nuwe stasie en die hoofposkantoor in werking en wanneer dit oor sowat 6 jaar voltooi is, sal dit ongeveer 2,800 voet lank wees en sowat 22,600 possakke per week vervoer. Daarna sal possakke slegs tussen die dokke en die hoofposkantoor per motorvoertuig vervoer word.

Hierdie moderne vervoergeriewe het vanselfsprekend die vervoer en hantering van ons pos baie bespoedig. In die Departement self is eweneens alles moontlik gedoen om die sortering en verdere behandeling van posstukke te bespoedig, maar die grootste enkele struikelblok hier is die geweldige omvang van die handearbeid wat steeds nodig is vir die behandeling van posstukke in groot getalle. Soos reeds aangedui, word meer as 1,100 miljoen posstukke tans jaarliks in die Republiek behandel en in weerwil van die grootste vereenvoudiging van sorteerprosesse is dit tans nog onmoontlik om pos met die spoed te behandel wat ons ons graag ten doel stcl. Bowendien neem die posverkeer standhoudend toe en omdat ons oortuig is dat die enigste oplossing in meganisering lê, is ons eerste briefsorteermasjien 'n ukkie gelede bestel. On : verwag om dit teen die einde van volgende jaar in Pretori $t$ in werking te hê en die beskikbaz theid daarvan sal 'n vel dere mylpaal wees in ons strewe om 'n brief wat vandag gepos is, môre by sy bestemming te lewer.

\section{Die telekommunikasiekant:}

Die vordering op hierdie gebied gee 'n ewe interessante geskiedenis wat ons vervolgens graag behandel. Te'egraafverbindings het natuurlik die telefoon vooruitgegaan. Telegrafie was trouens die eerste vorm van elektriese kommunikasie in SuidAfrika - dit dagteken uit die jaar 1860 toe die Telegraafmaat- 
skappy van die Kaap die Goeie Hoop 'n telegraaflyn tussen Kaapstad en Simonstad aangelê het - en daarom bepaal ons graag eerste die aandag by die telegraafdiens.

\section{Die telegraafdiens:}

Die eerste telegraafverbinding tussen Kaapstad en Simonstad word ongeveer in 1890 gevolg deur soortgelyke verbindings vanaf Kaapstad na Oos-Londen, Kingwilliamstown, Port Elizabeth en Grahamstad. Algemeen word aanvaar dat hierdie verbindings die eerste telekommunikasiekanale op die Vasteland van Afrika was, behalwe miskien in Egipte. Geleidelik is die telegraaflyne verleng en teen 1898 bereik hulle reeds die oewers van die Niassameer.

Die bekende morse-registreertoestel was die eerste telegraafapparaat en aanvanklik kon oor 'n enkele lyn slegs een boodskap op 'n keer oorgesend word. In 1882 is duplekswerking egter ingestel wat die draagvermoë van die bestaande lyne verdubbel het. 'n Paar jaar later volg 'n verdere verbetering toe kwadruplekswerking en dupleksherhalers in gebruik geneem is en in die jaar 1900 maak Wheatstone se outomatiese apparaat wat in die buiteland ontwikkel is, in Suid-Afrika sy verskyning. Danksy die ingebruikneming van hierdie apparaat kon tot 200 woorde per minuut oor 'n enkele kanaal oorgesend word. Dit word gevolg deur die ingebruikneming van Creedapparaat op die hooflyn tussen Johannesburg en Kaapstad in 1913. Deur hierdie apparaat wat die morsekode outomaties in Romeinse letters kon omsit, is 'n nuwe fase in die ontwikkeling van die druktelegraaf ingelui. In 1924 verskyn die teledrukker op die toneel waardeur die oorsending van berigte verder vereenvoudig en bespoedig word.

In 1910 was daar 12,516 myl telegraafverbindings. Teen 1935 was daar 20,900 myl en vandag is die verbindings baie naby 800,000 myl lank. Die teledrukker het die morse-instrument vir die grootste gedeelte vervang en dragfrekwensiestelsels is aangebring wat dit moontlik maak om talle telegraafkringe op 'n enkele lyn beskikbaar te stel. Die teleksdiens wat vandag die huurder van 'n teledrukker in staat stel om regstreeks met ' $n$ ander teledrukkerhuurder in feitlik enige deel van die wêreld in verbinding te tree, is in 1935 in gebruik geneem en sedertdien is outomatiese telekssentrales in Johan- 
nesburg, Kaapstad en Durban gestig. Binne die eersvolgende twee of drie jaar sal verdere soortgelyke sentrales in Pretoria, Port Elizabeth, Bloemfontein en elders geïnstalleer word, warna alle telekshuurders binne die Republiek deur 'n outomatiese skakelaksie regstreeks met mekar in verbinding sal kan tree.

Ten einde die ontvangs en versending van telegramme te vergemaklik en te bespoedig, is teledrukkers by hoofposkantore en later by die groter plattelandse poskantore geïnstalleer. Hierna volg die installering van skakeleenhede - deur ons eie manne ontwerp - en die ingebruikneming van outomatiese telegraaf-sentrales wat vandag talle telegraafkantore in staat stel om regstreeks met mekaar in verbinding te tree en sodoende omslagtige en tydrowende heroorsendings uitskakel. Tans is 314 telegraafkantore op dié wyse met mekaar verbind, maar teen die einde van 1968, wanneer die telegraafdiens in Suid-Afrika na verwagting ten volle geoutomatiseer sal wees, sal 530 telegraafkantore oor die hele Republiek regstreeks met mekaar in verbinding kan tree.

\section{Die telefoondiens:}

Toe die telegraafdiens indertyd in Suid-Afrika ingestel is, was dit nie net die enigste vorm van elektriese kommunikasie hier te lande nie, maar ter wêreld. Juis in daardie jare het Philip Reis van Frederichshof in Duitsland egter ' $n$ toestel ontwerp wat deur middel van 'n gehoorstuk en sender musiekklanke kon oorsein en ontvang. Hierdie uitvinding het gelei tot die ontwikkeling van die telefoon deur Alexander Graham Bell in die jaar 1876 en die stigting van die wêreld se eerste handtelefoonsentrale in New Haven Connecticut in die V.S.A. in Januarie 1878.

Suid-Afrika doen dadelik stappe om hierdie ontwikkeling te benut en slegs vier jaar nadat die telefoon uitgevind is, is reeds elf private telefoonstelsels met sewentien toestelle en 'n totale lynlengte van negentien myl in gebruik. Sedert daardie jare het geweldige ontwikkeling plaasgevind en die merkwaardigste vordering op die gebied van diensverskaffing deur die Poskantoor word vandag juis aan die telefoonkant aangetref.

Reeds in 1882 is die eerste handtelefoonsentrale op SuidAfrikaanse bodem geopen en wel in Port Elizabeth. Daarna volg Kaapstad in 1884, Oos-Londen in 1887, Pretoria in 1890 
en Johannesburg in 1894. In 1910 is daar reeds 90 sentrales wat altesaam 13,650 dienste verskaf. In die jaar 1922 - net tien jaar nadat die wêreld se eerste outomatiese sentrale by Epsom in Engeland in gebruik geneem is - word outomatiese sentrales by Kampsbaai (Kaapstad) en Waterkloof (Pretoria) gestig. Teen Januarie 1934 was daar sewentien outomatiese sentrales in werking en aan die einde van Maart 1938 was daar veertig wat ongeveer 107,000 huurders bedien het. Tans is daar 114.

Die eerste telefoonhooflyn is in 1886 oor 'n afstand van sewentien myl vanaf Kimberley na Rumpingstasie (Riverton) verskaf. In 1901 is 'n hooflyn tussen Kaapstad en Simonstad verskaf; in 1903 tussen Johannesburg en Pretoria en in 1906 tussen Durban en Pietermaritzburg. In die daaropvolgende jare is verskeie hooflyne oor kort afstande verskaf en tot 1922 was die gebruik van die hooflyndiens hoofsaaklik beperk tot verkeer tussen sentrales binne gebiede met 'n straal van ongeveer 200 myl. Langafstandkommunikasie was dus hoofsaaklik bewerkstellig deur middel van die telegraafdiens en die posdiens.

Gedurende 1922 maak 'n nuwe uitvindsel - die spraakfrekwensieversterker - dit moontlik om die eerste langafstand telefoonlyn tussen Johannesburg en Durban te verskaf en twee jaar later is Johannesburg en Kaapstad op dieselfde wyse met mekaar verbind. As gevolg van genoemde versterkers het langafstand telefoonverbindings vinnig toegeneem en die tempo is verder versnel deur die ontwikkeling van draagstelsels wat dit moontlik gemaak het om drie spraakkanale en agtien telegraafkanale uit een paar drade te verkry.

Omrede draagstelsels lyne van baie hoë gehalte vereis, is die ou roetes geleidelik sedert 1936 vervang. Vandag word die oorgrote meerderheid van ons telefoonkringe deur middel van draagstelsels voorsien. Suid-Afrika se bogrondse draagnet is trouens die tweede grootste in die wêreld. Die buitengewoon hoë gehalte van ons bogrondse draagroetes word duidelik weerspieël deur die feit dat die Republiek die eerste land ter wêreld is wat daarin kon slaag om soveel as agt-en-twintig telefoonkanale oor ' $n$ enkele paar drade te verskaf; die maksimum in die meeste ander lande is twaalf. Suid-Afrika word as ' $n$ gesaghebbende op hierdie besondere gebied in die wêreld erken. 
Bogrondse draagstelselroetes het egter besliste beperkings - daar kan byvoorbeeld slegs 300 spraakkanale oor dieselfde roete verskaf word - en daarom word van ondergrondse konsentriese kabels gebruik gemaak tussen sekere sentrums waar die telefoonverkeer dermate hoog is. Die eerste konsentriese kabel is in Januarie 1952 tussen Durban en Pietermaritzburg gelê, gevolg deur soortgelyke kabels tussen Kaapstad en Paarl, Johannesburg en Pretoria en Johannesburg en Vereeniging. Sodoende was dit moontlik om meer kanale oor een roete te voorsien. Die huidige kabel tussen Johannesburg en Pretoria maak byvoorbeeld voorsiening vir 1,920 spraakkanale.

Dit is van meer as gewone belang om net kortliks te let op die oorspronklike kabel tussen Johannesburg en Pretoria. (Dit was nie 'n konsentriese kabel nie). Hierdie kabel wat die ou bogrondse roete vervang het, is in 1936 langs die hoofweg tussen Pretoria en Johannesburg gelê. Dit was 36 myl lank en 280 rolle kabel wat nagenoeg $4 \frac{1}{2}$ ton elk geweeg het, is gebruik. Weens die gewig van die rolle moes spesiale sleepwaens ingevoer word om dit te vervoer en hantering moontlik te maak. Die koperdraad wat gebruik is, het byna 230 ton geweeg en verteenwoordig naastenby 22,000 myl enkele draadlengte.

Die grootste voorwaartse stap op die gebied van hooflyne is egter die mikrogolfstelsel wat heeltemal wegdoen met fisiese draad- of kabelverbinding. Die mikrogolfstelsel mak gebruik van radiofrekwensies wat só hoog is dat hulle byna dieselfde eienskappe as lig het. Hulle verswak naamlik vinnig namate die afstand toeneem en moet elke dertig of veertig myl versterk word. Net soos lig, word hulle ook deur fisiese obstruksies onderbreek en daar moet dus 'n skoon gesigslyn tussen die verskillende versterkers wees. As gevolg van hierdie eienskappe word mikrogolfstasies noodwendig op hoogliggende punte opgerig. Die seine word van punt tot punt oorgedra deur paraboolreflektors wat soos groot skottels lyk. Dié reflektors en die staaltorings wat 'n deel van die uitrusting uitmaak, is reeds ' $n$ algemene gesig in die platteland. Die hoogte van die toring wissel van 60 tot 300 voet.

Gedurende 1953 is ' $n$ begin gemaak met die installering van 'n eksperimentele mikrogolfstelsel tussen Pretoria en Johannesburg. Die toetse is in 1956 voltooi en gedurende 1960 is die eerste funksionele mikrogolfstelsel tussen Johannes- 
burg en Klerksdorp in gebruik geneem. Dit het aanvanklik 400 kringe verskaf maar kan tot 5,000 uitgebrei word. Die volgende stelsels is sedertdien verskaf:

Johannesburg-Welkom-Bloemfontein.

Johannesburg-Carletonville.

Johannesburg—Springs.

Durban-Scottburgh-Port Shepstone.

Johannesburg—Durban.

Die stelsel tussen Johannesburg en Durban wat op 1 Julie 1965 in gebruik geneem is, is nagenoeg 365 myl lank, het $\mathrm{R} 2,200,000$ gekos en maak voorsiening vir 7,000 spraakkanale nadat dit ten volle toegerus is.

Die volgende bykomende stelsels is reeds beplan en sal hopelik binne twee jaar in gebruik geneem kan word:

Johannesburg-Benoni.

Oos-Londen-Port Elizabeth.

Port Elizabeth-Bloemfontein.

Kaapstad-Port Elizabeth.

By voltooiing van hierdie stelsels, sal al die vernaamste stede in die Republiek deur middel van mikrogolfstelsels verbind wees.

Die volgende tabel dui die fenomenale uitbreiding van die hooflyndienste oor die vorige 40 jaar aan:

$\begin{array}{lrrrr} & 1926 & 1939 & 1948 & 1965 \\ \text { Getal kringe } & 798 & 1,996 & 2,806 & 13,293 \\ \text { Getal hooflyn- } & & & & \\ \text { oproepe per jaar } & 8,000,000 & 19,000,000 & 30,000,000 & 104,000,000 \\ \text { Hooflynmylafstand } & 72,000 & 132,000 & 157,000 & 1,000,000\end{array}$

As gevolg van die toenemende omvang van die hooflynverkeer, is die hooflyndiens geoutomatiseer en reeds is ' $n$ stelsel beskikbaar wat dit vir huurders in outomatiese gebiede moontlik maak om 139 handelsentrales regstreeks te skakel. Voorts sal die mikrogolfstelsel voldoene hooflyne tussen die vernaamste stede in ons land beskikbaar stel sodat die groot outomatiese telefoonnetwerke deur middel van outomatiese skakeling deur die huurders self, met mekaar verbind word. Hierdie diens staan bekend as Nasionale Huurdershooflynskakeling en afgesien van die hooflyne oor die mikrogolfstelsels moet outomatiese skakelapparaat ook geïnstalleer word om 
sodoende die onderlinge verbindings tussen die hooflyne te bewerkstellig. Hierdeur sal telefoonhuurders by verskillende sentrales onmiddellik met mekaar in verbinding kan tree deur slegs 'n sekere getal syfers te skakel. (Die maksimum sal tien wees).

Aan die outomatisering van plattelandse telefoonsentrales word volstoom gewerk. Daardeur word outomatiese skakeling ook na die kleiner dorpe uitgebrei en uiteindelik sal feitlik alle telefoonhuurders in die land mekaar outomaties kan skakel insluitende huurders op plaaslyne.

Laasgenoemde is moontlik gemaak deurdat ons eie ingenieurs ' $n$ outomatiese partylyntelefoon ontwerp het wat geheimhouding van telefoongesprekke verseker en elke telefoon oor afsonderlike kodeluie beskik wat nie op ander telefone op die lyn hoorbaar is nie. Huurders op partylyne kan dus self hul oproepe skakel en beskik vir alle praktiese doeleindes oor dieselfde diens as 'n gewone huurder, ondanks die feit dat 'n aantal huurders - tot 'n maksimum van tien - op dieselfde lyn bedien word.

Die eerste muntbusoproepkantoor is in 1906 in Kaapstad geïnstalleer en tans is daar ongeveer 16,000 in die Republiek. ' $n$ Tegniek waardeur 'n muntbusoproepkantoor by ' $n$ outomatiese stelsel aangesluit kon word, is juis in die Poskantoor se eie laboratorium ontwerp en vir die eerste keer in 1934 in Kaapstad in werking gestel. 'n Verdere prestasie wat ons behaal het is die ontwikkeling, in samewerking met sekere vervaardigers, van die transistor-tipe muntbus en -telefoon vir gebruik in oproepkantore. In vergelyking met die ou tipe is daar talle verbeterings aangebring insluitende ' $n$ transistormuntdetektor en 'n elektrodinamiese mikrofoon. Die nuwe eenhede wat die ou tipe geleidelik vervang, word in Suid-Afrika vervaardig. Nuwe tipe oproepkantooruitrusting is ook ontwerp sodat oproepkantoorgebruikers regstreekse skakelgeriewe kan geniet.

'n Belangrike ontwikkeling op telekommunikasiegebied is die oorsending van data. Deskundiges meen dat hierdie diens uiteindelik alle ander soorte telekommunikasie in omvang sal oortref. Die Poskantoor bied nou verskillende tipe data-oorsendingsgeriewe aan om aan die vereistes van die handel, die nywerheid, die staat en die wetenskap te voldoen. 


\section{Buitelandse-telekommunikasie:}

Op 27 Desember 1879 is telegrafiese verbinding tussen Suid-Afrika en Europa vir die eerste keer moontlik gemaak deur die opening van 'n ondersese kabel wat van Aden na Durban verleng is. Die kabel het aan die Eastern and South African Telegraph Company behoort en in 1902 is verbinding oor die ondersese kabelstelsel ook tussen Suid-Afrika en Australië oor Cocos bewerkstellig. Die Suid-Afrikaanse eindpuntstasie op Durban is met Kaapstad verbind deur 'n spesiale landlyn wat vir die eksklusiewe gebruik van internasionale verkeer gebou is.

Tans is daar regstreekse radiotelegraafverbindings met die Verenigde Koninkryk, die Verenigde State van Amerika, Wes-Duitsland, Switserland, Frankryk, Australië, Japan, die Demokratiese Republiek van die Kongo, Oos-Afrika, Angola en die Malagassiese Republiek. Ten spyte van die vyandige houding jeens die Republiek deur nuwe onafhanklike state in Afrika, is daar tot dusver geen poging aangewend om ons regstreekse kanale met die Kongo, Oos-Afrika en Malagassie te verbreek nie. Die eerste snelradiotelegraafverbinding met die buiteland is in 1927 tussen Kaapstad en Londen deur 'n private maatskappy ingestel. Aanvanklik was daar groot mededinging tussen die ondersese kabel- en radiomaatskappye. Later het die twee maatskappye egter saamgesmelt en in 1948 het die Poskantoor self die gebied van buitelandse telekommunikasie betree toe die Regering die belange van die betrokke maatskappy oorgeneem het.

Sedertdien het die vraag na buitelandse telefoon-, telegraafen teleksdiens so toegeneem dat die Poskantoor addisionele verbindings beskikbaar moes stel. Dit is gedoen deur in 1958 moderne send- en ontvangstasies by onderskeidelik Olifantsfontein en Derdepoort in gebruik te neem teen 'n gesamentlike koste van R2 miljoen. Dié twee stasies is van die heel modernste in die Suidelike Halfrond en verskaf meer as vyftig kringe na plekke soos Londen, New York, Sydney, Buenos Aires, Rio de Janeiro, Nairobi, Leopoldstad en Windhoek.

Danksy die beskikbaarheid van hierdie verbindings en landlyne na 'n groot aantal aangrensende gebiede, kan internasionale en interterritoriale telekommunikasieverkeer vandag met haas elke denkbare plek ter wêreld gewissel word. 
Die groei van die internasionale radiotelefoonverkeer sedert 1945 alleen blyk uit die volgende:

$\begin{array}{lrrr} & 1946 / 47 & 1957 / 58 & 1964 / 65 \\ \text { Oproepe na oorsee } & 5,754 & 17,724 & 23,846 \\ \text { Oproepe van oorsee } & 5,809 & 17,910 & 25,878\end{array}$

Met betrekking tot die interterritoriale telefoonverkeer spreek die volgende gegewens vir hulleself:

$\begin{array}{lrrrr} & 1935 & 1949 & 1958 & 1965 \\ \text { Oproepe na Rhodesië } & 5,616 & 24,306 & 84,214 & 153,272 \\ \text { Oproepe van Rhodesië } & 5,600 & 32,920 & 136,676 & 215,229 \\ \text { Opr. na Lourenco Marques } & 4,034 & 17,599 & 34,412 & 57,206 \\ \text { Opr. v. Lourenco Marques } & 2,591 & 18,565 & 30,082 & 57,741 \\ \text { Oproepe na Kenia } & - & 184 & 322 & 612 \\ \text { Oproepe van Kenia } & - & 293 & 577 & 739 \\ \text { Oproepe na Kongo } & - & 155 & 232 & 202 \\ \text { Oproepe van Kongo } & - & 216 & 259 & 198\end{array}$

Vir jare reeds is die radio die enigste wyse waarop skepe ter see met die land in verbinding kan bly. Vir dié doel is dwarsdeur die wêreld radiostasies aangebring en in Suid-Afrika is die eerste kusradiotelegraafstasie in 1910 in Durban opgerig. Die stasie het uit 'n 3-kw-vonkstelsender, 'n kohererontvanger en 'n morse-inktoestel bestaan en kon in daglig met skepe oor ' $n$ afstand van sowat 250 myl in verbinding tree. 'n Verdere kusstasie met ' $\mathrm{n} 5 \mathrm{kw}$-sender van die draaivonktipe is gedurende dieselfde jaar by Slangkop naby Kaapstad opgerig. In 1939 is die ontvangsapparaat van Slangkop na Kommetjie verskuif: die send- en ontvangsdienste word nou op onderskeidelik Klipheuwel en Milnerton verrig. Geriewe bestaan tans in Kaapstad, Port Elizabeth, Durban en Walvisbaai (in Suidwes-Afrika) vir radiotelegraaf- en telefoonverbindings met skepe ter see. Kaapstadradio is ook met hoë-frekwensietelegraafapparaat toegerus en is in staat om met skepe in enige deel van die wêreld in verbinding te tree.

Tradisioneel word deur middel van die morsekode met skepe ter see in verbinding getree en internasionale kodeseine is opgestel om taalprobleme te oorbrug. Telefoondienste word egter in toenemende mate gebruik en 'n hele aantal mo- 
derne skepe is dan ook reeds met teledrukkers toegerus. In hierdie stadium is daar egter nog betreklik min kusradiostasies wat toegerus is om teledrukkerwerking met skepe aan te gaan. In die meeste gevalle kan teledrukkers op skepe slegs gebruik word wanneer hulle in die dokke met plaaslike teleksnette verbind kan word. Dit val egter nie te betwyfel nie dat kusradiostasies dwarsdeur die wêreld in die toekoms geriewe vir teledrukkerverbinding met skepe sal moet verskaf en dat die tradisionele morsestelsel deur die telefoon en die teledrukker vervang sal word.

Volgens amptelike registers van die Internasionale Telekommunikasie-unie, bestaan daar tans 64 kusradiostasies vir verbinding met vaartuie op internasionale seeroetes aan die kuslyn van die Vasteland van Afrika. Daar is ook 'n kusstasie by Matadi op die Kongorivier en vier aan die oewers van die Malawimeer wat kommunikasie met die talle meerbote moontlik maak.

Die eerste volle outomatiese mobiele landradiotelefoondiens in die Republiek is op 24 Maart 1964 by wyse van proefneming aan die publiek in Johannesburg beskikbaar gestel. Hierdie diens stel 'n huurder in staat om in sy private voertuig binne 'n straalgebied van ongeveer dertig myl van die kontrolestasie af plaaslike sowel as hooflynoproepe te maak en te ontvang.

Fototelegramme kan vandag sowel binnelands as met verskillende lande in die buiteland gewissel word. Regstreekse radioverbindings bestaan vir die ontvangs en versending van fototelegramme van en na die Verenigde Koninkryk en die V.S.A. Ten einde verlies van beeldskerpte uit te skakel wat by heroorsending voorkom, word fotos by ontvangs op 'n snelheidsbeheerde band opgeneem. Daarna kan heroorsending soveel keer as wat nodig is sonder verlies van beeldskerpte geskied.

\section{Telekommunikasiedienste elders in Afrika:}

Soos heel aan die begin aangedui, weet ons dat telekommunikasie-ontwikkeling in Afrika veral vir sover dit die nuut gestigte state betref, nie 'n gevorderde stadium bereik het nie. Dit spreek onder meer daaruit dat, in die jongste jare veral, groot druk by internasionale vergaderings deur die Afrikastate uitgeoefen is vir tegniese hulp om hulle tele- 
kommunikasieverbindings te moderniseer en uit te brei. Dit is dus ' $n$ billike afleiding dat meeste van die Afrikastate hoegenaamd nie hierin selfstandig kan optree en noemenswaardige verbeterings kan aanbring nie, maar dat hulle feitlik geheel en al afhanklik is van geldelike, tegniese en administratiewe hulp van die res van die wêreld.

Verskillende konferensies van die Ekonomiese Kommissie vir Afrika en die Internasionale Telekommunikasie-unie is reeds gehou, waarvan die jongste in Maart 1966 in Addis Ababa, Ethiopië. Hierdie vergadering is spesiaal gereël om die ontwikkeling van telekommunikasies in Afrika te bevorder om sodoende die ontwikkelende lande op ekonomiese en sosiale gebiede te bestendig. In sy verwelkomingsrede by dié geleentheid het Haile Selassie van Ethiopië gesê dat die uitbreiding en verbetering van die inter-Afrikaanse telekommunikasienet van primêre belang is om Afrika-eenheid te bewerkstellig. $\mathrm{Hy}$ het aangevoer dat solank die telekommunikasiestelsel van Afrika van transitosentrums buite Afrika afhanklik bly, die ontwikkeling van Afrika op alle gebiede ernstig gekortwiek sal word.

Onder meer was hy moontlik daarop bedag dat van die getal kringe wat uitsluitlik vir die openbare telegraafdiens gebruik word, slegs 24 in Nigerië, nege in die Demokratiese Republiek van die Kongo en 76 in die Kameroen is. Die vergelykende syfer vir die Republiek is 385 .

Volgens die syfers van binnelandse telegraafverkeer het Zambië ook slegs 476 telegramme in 'n jaar gehanteer. Enkele beskikbare syfers van die getal telegramme wat jaarliks in ander lande in Afrika behandel word, is soos volg:

Nigerië ..................................................................... 190,000

Oos-Afrika (Kenia, Oeganda, Tanganjika) ...... 1,690,000

Egipte …................................................................ 2, 2,480,000

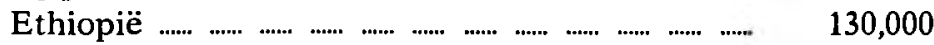

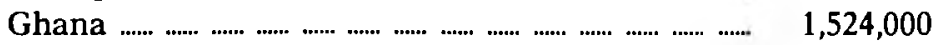

Malagassie ................................................................... 94, 943,000

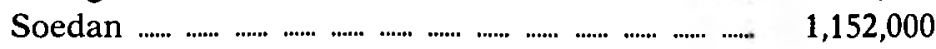

Togoland ................................................................... 46, 4600

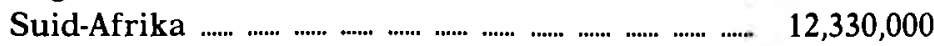

Op 1 Januarie 1965 was in 'n paar Afrikalande die getal telefone per 100 inwoners soos volg: 
Basoetoland ......................................................................

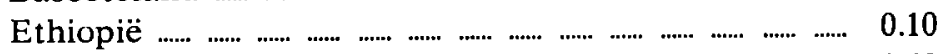

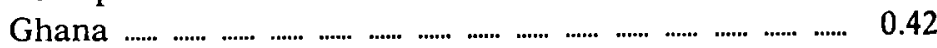

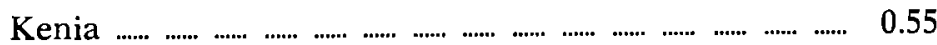

Nigerië ................................................................................ 0.11

Rhodesië ........................................................................ $\quad$..... 2.25

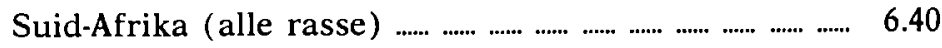

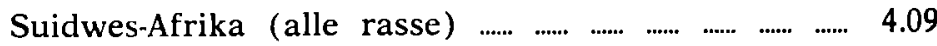

Egipte ................................................................................... 1.03

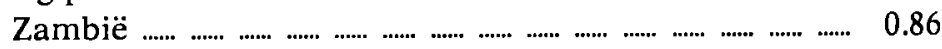

Op dieselfde datum was die getal telefone in enkele Afrikalande soos volg:

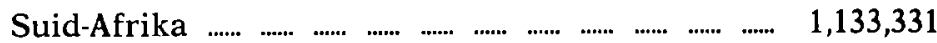

Egipte ....................................................................... $\quad$..... $\quad 301,405$

Marokko ...................................................................... $\quad$ 146,684

Rhodesië ...................................................................... $\quad 94,887$

Kenia, Oeganda en Tanganjika ................................ $\quad 89,315$

Nigerië .......................................................................... $\quad$..... 60,428

Ethiopië ............................................................................ 21,404

Altesaam is daar ongeveer 2,359,700 telefone in Afrika, waarvan baie naby $50 \%$ in Suid-Afrika bestaan.

Dit mag wees dat op kommunikasiegebied elders in Afrika vandag ontwikkelings aan die gang is waarvan ons in SuidAfrika nie weet nie en dat enkele van die Afrikastate reeds daarop aanspraak sal wil maak dat ook hulle reeds oor moderne outomatiese en moontlik gevorderde telefoon- en telegraafstelsels beskik. Maar selfs dan toon voorgaande statistiek onteenseglik dat die hele Afrika met uitsondering van hoogstens een of twee state hoegenaamd nie oor telekommunikasiestelsels beskik wat in dieselfde asem as dié van SuidAfrika genoem kan word nie.

Toekomstige ontwikkelings:

Ondanks die geweldige ontwikkeling soos hierin geboekstaaf, blyk by nadere beskouing dat die verbeterings in die stelsel hoofsaaklik tot ontwerp, tegnieke en onderdele beperk is en dat die basiese beginsels met min uitsondering in werklikheid oor die jongste dekade of twee weinig verander het. 
Selfs die moderne kruisstelsel wat algemeen gebruik word, berus nog op dieselfde beginsels as die ou relais outomatiese stelsel wat in 1912 deur Betulander en Palgren uitgevind is. Die jongste ontwikkelings met betrekking tot konsentriese kabelstelsels en mikrogolfstelsels het egter 'n nuwe tydvak op hierdie besondere gebied ingelui. Getransistoriseerde draag-, radio- en ander spesiale uitrusting is reeds beskikbaar en uit die Verenigde Koninkryk kom die nuus dat 'n elektroniese telefoonsentrale so pas daar in gebruik geneem is. Met behulp van hierdie uitvindsel en ander wat van tyd tot tyd beskikbaar kom, is dit moontlik dat die telekommunikasiestelsel soos ons dit vandag ken, teen die einde van die huidige eeu plek sal gemaak het vir 'n ultra-moderne stelsel waarmee die hele wêreld verbind sal wees deur konsentriese kabels, ionosferiese en troposferiese verstrooiingstelsels en deur interkontinentale kanale wat van handgemaakte satelliete weerkaats word.

Interkontinentale kommunikasie deur middel van herhalers in rondbewegende satelliete bevind hom trouens reeds in die stadium waar praktiese proewe gedoen word. Suid-Afrika, asmede talle ander nasies, is vennote in die Voorlopige Internasionale Satellietkommunikasiekomitee wat 'n wêreldwye net van Satellietverbindings beoog. Proefondervindelik is die eerste kommunikasie satelliet (Early Bird) reeds gelanseer en ofskoon daar nog baie navorsing gedoen sal moet word, is dit waarskynlik dat satelliete in die toekoms 'n groot rol sal speel in die wêreldwye telekommunikasienetwerk wat reeds vinnig gestalte aanneem.

Van groter onmiddellike belang vir Suid-Afrika, is egter die beoogde nuwe ondersese kabel na Europa. Oor die jare heen is ons oorsese radiogeriewe gedurig uitgebrei om in die toenemende behoeftes te voorsien, maar na 1967 sal geen verdere uitbreiding oor die radio moontlik wees nie omrede alle frekwensies. in die bruikbare bande dan ten volle opgeneem sal wees. Terwyl hoëfrekwensieradio geskik is vir telegraafbediening (aangesien foutkorrigering van seine plaasvind) wissel die gehalte van telefoon-oorsending aansienlik as gevolg van veranderings in die ionosfeer. Daarom het SuidAfrika onlangs die voortou geneem met die beplanning van ' $n$ moderne ondersese telefoonkabel tussen Suid-Afrika en Europa en in hierdie stadium word verwag dat dit oor ongeveer twee 
of drie jaar in diens geneem sal kan word. Die kabel is een van die grootste telekommunikasieprojekte wat ooit aangepak is en die eerste diepsee langafstandkabel wat oor 'n draagvermoë van soveel as 360 kanale sal beskik. Die projek sal ongeveer R50,000,000 kos en wanneer die kabel gereed is, sal ' $n$ oproep na enigeen van meer as 150 miljoen telefone en naastenby 'n halfmiljoen teledrukkers met min of geen vertraging moontlik wees.

\section{Internasionale organisasies:}

Die internasionale telekommunikasie-unie:

Die Internasionale Telekommunikasie-unie (ITU) het gedurende 1965 sy honderdste bestaansjaar herdenk. Hierdie organisasie waarvan feitlik elke land in die wêreld vandag lid is, is gestig met die doel om reëls op te stel en standaarde neer te lê vir die ordelike ontwikkeling en bedryf van telekommunikasiedienste tussen lede-lande.

Suid-Afrika se bande met die ITU dateer vanaf 1881 toe die ou Kaap-kolonie lid van die organisasie geword het. Vanaf daardie jaar was Suid-Afrika by al die vernaamste internasionale telekommunikasiekonferensies verteenwoordig en het hy 'n aktiewe deelname aan die werksaamhede van die ITU gehad. In die jongste tyd - soos ook elders - is ongelukkig toegelaat dat politieke oorwegings die werksaamhede van die Unie ernstig beïnvloed. Vir ongeveer 100 jaar het die organi. sasie hom geheel en al van politiek weerhou en hom hoofsaaklik by sy doelstellings bepaal, maar by die Gevolmagtigde Konferensie in Montreux verlede jaar is Suid-Afrika sy regte om aan die verrigtings van die Konferensie deel te neem deur 'n meerderheidstemming ontsê. Hierdie onwettige besluit is geneem bloot op grond van politieke verset teen die Republiek en sonder inagneming van die feit dat Suid-Afrika sonder versuim al sy verpligtinge teenoor die organisasie nagekom het. In een stadium was daar 'n wesentlike gevaar dat SuidAfrika sy lidmaatskap van die Organisasie sou moes verbeur, maar gelukkig het verantwoordelike denke geseëvier.

Pos- en Telekommunikasie-unie van Afrika:

Gedurende 1928 het die destydse Posmeester-generaal van 
die Unie van Suid-Afrika, die gedagtes van administrasies in sekere Britse gebiede, soos Suid- en Noord-Rhodesië, Njassaland en Tanganjika, geprikkel met die idee dat dit voordelig sou wees om sake soos die uitbreiding van telegraaf- en telefoonstelsels, die instelling van radiodienste en die kwessie van tariewe, wat van gemeenskaplike belang vir daardie administrasie was, van tyd tot tyd te bespreek met die doel om 'n sentrale liggaam te stig om uitvoering aan besluite te gee.

Hierdie idee het vermoedelik ontstaan as gevolg van die probleme om doeltreffende telekommunikasieverbindings te bewerkstellig. Tegnici was skaars en Suid-Afrika met sy gevorderde stelsels en kennis van pos- en telekommunikasie-aangeleenthede, kon hulp verleen en leiding gee aangesien hy altyd op internasionale konferensies verteenwoordig was.

Uit die staanspoor uit was dit duidelik dat die beweging wat op klein skaal aangepak is al hoe meer byval onder ander Afrika-lande gevind het en dit was dus nie onverwags nie toe verteenwoordigers van ' $n$ aantal lande in Julie 1935 in Kaapstad vergader het om die Pos- en Telekommunikasie-unie van Afrika te stig. Die oorspronklike lede van die Unie was:

Angola, Belgiese Kongo (met inbegrip van Ruanda en Urundi), Basoetoland, Betsjoeanaland, Swaziland, Mosambiek, Noord- en Suid-Rhodesië, Njassaland, Uganda, Kenia, Tanganjika, Suidwes-Afrika en die Unie van Suid-Afrika. (Frans-Ekwatoriaal-Afrika het in 1941, die Frans-Kameroen in 1942 en Madagaskar in 1948, by die Unie aangesluit).

Tydens die eerste konferensie van verteenwoordigers van lidlande, wat gedurende Oktober 1935 in Kaapstad gehou is, is sekere ooreenkomste aangegaan om die verbetering van die organisasie en pos- en telekommunikasiedienste tussen lidlande te verseker. Verdere konferensies is gedurende 1939 en 1948 in Kaapstad gehou.

Die administrasie van Suid-Afrika is aangewys om as Buro van die Unie op te tree met die doel om inligting van gemeenskaplike belang onder lede te versprei. (Alle onkostes in hierdie verband is deur Suid-Afrika gedra). Engels, Frans en Portugees is as amptelike tale aanvaar.

$\mathrm{Na}$ die eerste drie konferensies is onsuksesvolle pogings aangewend om verdere konferensies in 1953 en 1960 in Leopoldstad te hou. Daarna en omdat die bestaande ooreenkomste met die verloop van tyd verouderd geraak het hersien moes 
word, het Suid-Afrika in 1963 die voortou geneem en aangebied om 'n konferensie van alle lidlande in Johannesburg te huisves. Ook hiervan het niks tereggekom nie. Vandag word feitlik geen aandag meer aan die oorspronklike ooreenkomste geheg nie en die gebrek aan belangstelling bedreig trouens die voortbestaan van die Unie.

Die lidmaatskap is tans soos volg:

Angola, Basoetoland, Betsjoeanaland, Republiek van Burundi, Demokratiese Republiek van die Kongo, Malawi, Mosambiek, Republiek van Suid-Afrika, Rhodesië, Suidwes-Afrika, Swaziland en Zambië. (Laasgenoemde onttrek op 31 Mei 1966).

\section{Die Wêreldposunie:}

Die Wêreldposunie is op 1 Julie 1875 in die lewe geroep. Sy hoofdoelstellings, soos hieronder weergegee, het deur die jare heen onveranderd gebly.

„The countries adopting this Constitution comprise under the title of the Universal Postal Union, a single postal territory for the reciprocal exchange of letter post items. Freedom of transit is guaranteed throughout the entire territory of the Union.

The aim of the Union is to secure the organisation and improvement of the postal services and to promote in this sphere the development of international collaboration."

Suid-Afrika se verbintenis met die Wêreldposunie dateer terug na die negentigerjare toe Natal en Zoeloeland op 1 Julie 1892, die Suid-Afrikaanse Republiek op 1 Januarie 1893, die Kaapkolonie op 1 Januarie 1895 en die Oranje Vrystaat op 1 Januarie 1898 lidlande daarvan geword het. Op 1 Junie 1910 het die destydse Unie van Suid-Afrika tot die Posunie toegetree.

Sedert 1920 word die Aktes van die Posunie min of meer elke vyf jaar deur 'n kongres hersien. Die kongres word saamgestel deur verteenwoordigers van lidlande. 'n Afgevaardigde van die Suid-Afrikaanse Republiek het die Weense Kongres van 1891 bygewoon - moontlik met die oog op toetrede tot die Unie wat in 1893 gevolg het. Die eerste kongres na die totstandkoming van die Unie van Suid-Afrika is in 1920 in Madrid gehou. Vanaf daardie jaar was Suid-Afrika op al die kongresse 
van die Posunie verteenwoordig.

Die Paryse Kongres (1947) het 'n Uitvoerende en Skakelkomitee, bestaande uit 20 lidlande wat op 'n geografiese grondslag gekies word, in die lewe geroep. Dié komitee behartig dringende en aktuele sake van die Posunie tussen kongresse. Die eer het Suid-Afrika te beurt geval om sedert die Brusselse Kongres (1952) tot die Weense Kongres (1964) op dié komitee te dien, en wel in die hoedanigheid van vise-voorsitter van die xomitee self en ook as voorsitter en vise-voorsitter van sekere van die subkomitees. Lidlande mag slegs by twee agtereenvolgende kongresse genomineer word om op die komitee te dien, en afgesien van enige ander oorwegings was Suid-Afrika nie weer in 1964 herkiesbaar nie.

Die Wêreldposunie se hoofkantoor is in Bern, Switserland, gesetel. Vir die doel van die instandhouding van die kantoor (algemeen bekend as die Internasionale Buro van die Wêreldposunie) en die betaling van ander uitgawes van die Posunies, word lidlande in klasse 1 tot 7 verdeel om tot die uitgawes by te dra. ' $n$ Eersteklas lid se bydrae is 25 eenhede van die totaal, terwyl dié van 'n sewendeklas lid maar 1 eenheid is. Die Posunie het tans 128 lede en slegs 17 van hulle is eersteklas lede. Suid-Afrika - terloops die enigste land in Afrika ressorteer onder dié 17.

Interessantheidshalwe word die volgende tabel in verband met die klasindeling en verspreiding van uitgawes verstrek:

$\begin{array}{cccc}\text { Klas } & \begin{array}{c}\text { Getal Pos- } \\ \text { administrasies }\end{array} & \begin{array}{c}\text { Getal } \\ \text { eenhede }\end{array} & \begin{array}{c}\text { Totale getal } \\ \text { eenhede }\end{array} \\ 1 & 17 & 25 & 425 \\ 2 & - & 20 & - \\ 3 & 14 & 15 & 210 \\ 4 & 10 & 10 & 100 \\ 5 & 12 & 5 & 60 \\ 6 & 31 & 3 & 93 \\ 7 & 44 & 1 & 44 \\ & 128 & & 932\end{array}$

Dit is van belang om te weet dat die bydrae van sewende klas lede nie eers die koste van die publikasie dek wat die Buro aan hulle stuur nie. 
Die heel belangrikste funksie van die Wêreldposunie is waarskynlik dié in verband met deurgangspos, dit wil sê pos wat posadministrasie A deur die land van posadministrasie B (of selfs meer tussengeleë posadministrasies) na posadministrasie C stuur. Die Posunie het vasgestelde tariewe vir die doel (wat gewoonlik by kongresse hersien word) en die hoeveelheid pos wat hierby betrokke is, word driejaarliks deur middel van 'n gewigsensus bepaal. Suid-Afrika hanteer 'n aansienlike hoeveelheid deurgangspos en die bedrag wat hy hiervoor in, tel onder die vier hoogstes ter wêreld.

M. C. Straus.

Pretoria.

25 Mei 1966. 